“Solid-phase synthesis of modified oligonucleotides”. Eritja R.

Int. J. Pept. Res. Ther., 13(1-2), 53-68 (2007).

doi: 10.1007/s10989-006-9053-0

\title{
Solid-phase synthesis of modified oligonucleotides ${ }^{1}$
}

\section{Ramon Eritja}

Institute for Research in Biomedicine (IRB), CSIC, Barcelona Science Park, Josep

Samitier 1-5, E-08028 Barcelona, Spain

Abbreviated title: synthesis of oligonucleotides

Corresponding author:

Ramon Eritja

Institute for Research in Biomedicine (IRB), CSIC,

Barcelona Science Park,

Josep Samitier 1-5,

E-08028 Barcelona, Spain

Phone +34-93-4039942

Fax +34-93-4037114

Email: recgma@cid.csic.es

\footnotetext{
${ }^{1}$ This work is dedicated to the memory of Bruce Merrifield.
} 
Key words: oligonucleotide, non-natural bases, oligonucleotide-peptide conjugates, nanomaterials, self-assembly, solid phase synthesis.

\begin{abstract}
Synthetic oligonucleotides are ubiquitously found in most laboratories since solid-phase synthesis protocols have become highly optimized. These protocols make it possible to synthesize a large variety of modified oligonucleotides. As one example, we will review some of the developments regarding oligonucleotide synthesis from our own group. In particular, we will describe the synthesis of oligonucleotides carrying non-natural bases, of oligonucleotide-peptide conjugates, and of modified oligonucleotides used in the assembly of nanomaterials.
\end{abstract}




\section{Introduction}

The identification of DNA as the basis of genetic material and the elucidation of its structure stimulated attempts to undertake the complex synthesis of defined oligonucleotides. In 1955, two years after the report on the double-helix structure by Watson and Crick, the first synthesis of a dinucleotide was published (Michelson and Todd, 1955). During the next 20 years solution-phase methods were used to synthesize oligonucleotides employing the "phosphodiester" approach developed by the Khorana group (Khorana, 1979).

The "phosphotriester" methodology was subsequently developed (Reese, 1978) and afterward, solid-phase methodology was introduced. Immediately after Merrifield's solid-phase synthesis of the tetrapeptide Leu-Ala-Gly-Val (Merrifield, 1963), Letsinger synthesized an oligonucleotide using solid-phase supports (Letsinger and Mahadevan, 1965). Although it was not until the end of the 1970s that solid-phase protocols were developed, with certain improvements, and they became the method of choice for the preparation of oligonucleotides. The newly developed phosphotriester methodology was suitable for solid-phase synthesis, prompting development of linkers and supports. In the mid-1970s synthetic cycles became automated and HPLC began to be used for the purification of oligonucleotides. In addition, DNA synthesizers appeared and oligonucleotides became available for biochemical and molecular biology studies.

At the same time that automation of the DNA synthesis was underway, the Letsinger group realized the potential of phosphorous III derivatives, exploiting their exceptional reactivity (Letsinger and Lunsford, 1976) to develop the phosphite-triester method. Shortly afterwards, Beaucage and Caruthers developed the nucleoside phosphoramidites 
(Beaucage and Caruthers, 1981) which could be synthesized, stored, and activated by tetrazole to yield phosphite-triester intermediates that were subsequently transformed via oxidation to phosphate-triester (Fig. 1). Nowadays, phosphoramidite derivatives remain the most widely used for oligonucleotide synthesis, allowing for the preparation of oligonucleotides with natural phosphodiester bonds or with modified phosphates such as phosphorothioates. A large number of developments in nucleic acid chemistry achieved with the phosphoramidite approach can be found in the superb reviews by Beaucage and Iyer (Beaucage and Iyer, 1992, 1993a, b,c).

\section{Figure 1}

In solid phase methods, the 3'-end of the first nucleoside is attached covalently to a polymeric support. In this way, the oligonucleotide chain grows on the polymeric support with the excess chemicals used during synthesis washed out, thus simplifying the synthetic process (Figure 1). In addition, solid-phase techniques made possible the automation of the synthetic process and oligonucleotide synthesizers became increasingly available to most laboratories.

Although the supports used in the first protocols employing phosphotriester methodology were similar to peptide synthesis (polystyrene and polyamide), machineassisted synthesis of oligonucleotides was soon adopted for silica-derived supports such as controlled-pore glass (CPG) (Matteucci and Caruthers, 1981, Gait, 1985, Agrawal, 1993, Narang, 1987, Caruthers et al., 1987). These supports give better yields, possess good mechanical properties, and do not swell in organic solvents. Highly cross-linked polystyrene was subsequently developed for small-scale use (20-200 nmol) due to its hydrophobic properties and the lack of reactivity of its surface (McColum and Andrus, 
1991). For large-scale synthesis, several alternative supports have been described, such as those composed of polystyrene (Montserrat et al., 1994) or polystyrenepolyethyleneglycol (Wright et al., 1993).

Here, we will review some of the developments in oligonucleotide synthesis originating with our own group. As my Ph. D. thesis addressed solid-phase peptide synthesis (Giralt et al., 1981, Giralt et al., 1986), an important part of our research focuses on synthetic methodology for the preparation of modified oligonucleotides. However, due to the important biological properties of DNA, these synthetic efforts have been mainly directed towards producing compounds that solve biological and/or structural questions.

\section{RESULTS AND DISCUSSION}

\section{The properties and synthesis of oligonucleotides carrying modified bases of biological and structural interest.}

The phosphoramidite approach allows for the preparation of oligonucleotides containing not only the natural bases, but also a large number of non-natural nucleosides. Oligonucleotides containing non-natural bases are being used in structural studies to analyze DNA-DNA and DNA-protein interactions as well as in model compounds for the study of mutagenesis and the repair of mutagenic lesions (Basu and Essigmann, 1988).

Structural elucidation of the mutagenic properties of 2-aminopurine, 5-fluoro and 5bromouracil

2-Aminopurine (AP) is an adenine (A) isomer in which the exocyclic amino group occurs at position 2 instead of position 6. While AP preferentially forms base pairs with 
thymine (T) during DNA synthesis, it may also form base mispairs with cytosine (C), causing A.T to G.C transitions. The substitution of the methyl group at position 5 of thymidine with bromine or fluorine yield nucleosides that exert important chemotherapeutic activity. As thymidine analogues, 5-fluoro (FU) and 5-bromouracil (BrU) derivatives noy only form base pairs with adenine, but also, base mispairs with guanine (G). The mutagenic properties of AP, FU, and BrU stem from the formation of anomalous base pairs with natural bases, primarily resulting in the higher stabilities of AP.C, FU.G and BrU.G base mispairs. To investigate this latter phenomenon, defined sequence oligonucleotides containing these modified bases were prepared and studied using NMR techniques. Three possible structures were proposed for these mispairs (Fig. 2), including those involving a neutral wobble structure, a rare tautomer (enol for FU and BrU and imino for AP), and ionized forms (the protonated form for AP and the deprotonated form for BrU and FU). NMR studies on DNA duplexes carrying these modified mispairs show the presence of a pH-dependent equilibrium between a wobble geometry and an ionized structure in Watson-Crick geometry (Fagan et al., 1996, Gargallo et al., 2001, Law et al., 1996, Sowers et al., 1986, 1988, 1989a, 1989b, 2000). For 5-substituted uracil derivatives, the ionized structure was shown to be responsible for the higher mispair frequency (Yu et al., 1993).

\section{Figure 2}

To prepare those oligonucleotides carrying AP, we prepared a protected derivative (Fig. 3, Eritja et al., 1986a). First, 2-aminopurine 2'-deoxyriboside was synthesized by transglycosylation (Sowers et al., 1989c). The $N$-isobutyryl derivative was then prepared by modifying the transient protection procedure (Ti et al., 1982). This method 
allowed for the preparation of DNA duplexes carrying the four nitrogen atoms in the AP.C mispair with ${ }^{15} \mathrm{~N}$, which is essential for NMR studies (Sowers et al, 1989b and 1989c). An easier method for the selective introduction of ${ }^{15} \mathrm{~N}$ labels at the exocyclic position of AP was developed (Acedo et al., 1994). The key step of this method is the preparation of the phosphoramidite (derivative) of 2-fluoropurine 2'-deoxyriboside. This derivative can be incorporated at a specific position within an oligonucleotide sequence and during deprotection can be transformed to the desired ${ }^{15} \mathrm{~N}$ labelled nucleoside (Fig. 3). This strategy, know as the convertible nucleoside (MacMillan and Verdine, 1991) or postsynthetic substitution approach (Xu et al., 1992), has been used for introduce sensitive bases and other groups that are difficult to incorporate using the classical method.

\section{Figure 3}

At present, the phosphoramidite derivative of 2-aminopurine is prepared by reduction of guanosine derivatives (Figure 3, McLaughlin et al., 1988, Connolly, 1992, Schmidt and Cech, 1995, Fujimoto et al., 1996). It is then used as a fluorescent adenine substitute to study those proteins that interact with DNA (Beechem et al., 1998, Bloom et al., 1994, Holz et al., 1998, Raney et al., 1994).

Studies on non-natural bases that may base pair equally well with the four natural bases (universal base)

A particular problem on the use of oligonucleotides as probes involves finding a nucleoside and non-nucleoside derivative that can base pair equally well with the four natural bases to act as an (universal base). This is needed to prepare DNA probes in 
which the nucleic acid sequence is not completely known. This often occurs when designing oligonucleotide probes from protein sequences due to degeneration of the genetic code. 2'-Deoxyinosine (Fig. 4a) was the first compound studied and remains one of the most used for this purpose (Ohtsuka et al., 1985). Its ribonucleoside derivative, inosine, was found in t-RNA at the third position of the anticodon, and proved capable of pairing the $\mathrm{A}, \mathrm{C}$ and $\mathrm{U}$ bases of the anticodon. Oligonucleotides carrying 3-nitropyrrole (Fig 4e, Nichols et al. 1994) and 5-nitroindole (Fig 4f, Loakes and Brown, 1994, Loakes et al., 1995) at several sites were used as primers for sequencing and polymerase chain reaction (PCR, Mullis et al. 1986). These analogues are designed to maximize base stacking, thereby minimizing hydrogen-bonding interactions.

\section{Figure 4}

Another approach is to modify 2'-deoxyinosine in the hopes of obtaining better base pairing properties. Introduction of a hydrogen bond acceptor in position 2 yields a purine analogue derived from 2'-deoxyinosine that contains the configuration of hydrogen binding groups: acceptor-donor-acceptor. This allows the construction of base-pairing structures with two hydrogen bonds for the four natural bases. The preparation of synthetic oligonucleotides containing xanthine (Fig. 4b), the first base analogue of this type, was reported (Eritja et al., 1986b). Xanthine-containing oligonucleotides were found to have a low melting temperature under neutral $\mathrm{pH}$ conditions, due to the ionization of xanthine at a similarly neutral $\mathrm{pH}\left(\mathrm{pK}_{\mathrm{a}}\right.$ of xanthosine 5.5). It was also shown that xanthine base pairs become more stable at $\mathrm{pH} 5.5$ (Eritja et al., 1986b). 
Xanthine-containing oligonucleotides are of added interest since xanthine may be present in DNA as a by-product of the spontaneous guanine deamination. Incorporation of base mispairs opposite template xanthine sites by Drosophila DNA polymerase $\alpha$ showed that $\mathrm{T}$ and $\mathrm{C}$ were incorporated opposite xanthine. These data do not correlate with the relative thermodynamic stabilities obtained from melting curves suggesting that DNA polymerase misinsertion rates are greater when the base pair forms in accordance with Watson-Crick geometry (Eritja et al., 1986). This hypothesis has been further studied by several authors and excellent reviews are available (Kool, 2001 and Benner, 2004).

Substitution of the keto group by a nitrogen atom at position 2 in xanthine yields a base analogue, 2-azahypoxanthine (Fig. 4c) that shares the same acceptor-donor-acceptor configuration, albeit with a higher $\mathrm{pK}_{\mathrm{a}}\left(\mathrm{pK}_{\mathrm{a}}\right.$ of 2-azainosine 6.8). Attempts to synthesize oligonucleotides containing 2-aza-2'-deoxyinosine (using a protected derivative with the $N, N$-diphenylcarbamoyl group) failed, due to an unexpected side-reaction of the protected derivative during the final ammonia treatment (Fernández-Forner et al., 1991). Protection of 2-azahypoxanthine moiety with the photolabile 2-nitrobenzyl group allowed for the preparation of oligonucleotides containing 2-azahypoxanthine (Acedo et al., 1995). Melting curves for duplexes carrying 2-azahypoxanthine paired with the four natural bases proved that 2-azahypoxanthine base pairs were less stable than perfectly matched duplexes, although little variation was evident among different bases (Acedo et al., 1995).

A similar result was found during the synthesis of oligonucleotides carrying 8-amino2'-deoxyinosine (Fig. 4d, Cubero et al., 2001). As explained below, the presence of an amino group at position 8 of the purines not only stabilizes DNA triplexes, but also induces a small destabilization of the duplex carrying the 8-aminohypoxanthine-C base 
pair. In this way, the differences in the melting temperatures of the duplexes carrying 8aminohypoxanthine paired with the four natural bases were similar to those reported for 3-nitropyrrole and 5-nitroindole. Only 8-aza-7-deaza-2'-deoxyadenosine (Seela and Debelak, 2000) had better binding properties than 8-aminohypoxanthine (Cubero et al. 2001).

Preparation of oligonucleotides carrying ammonia sensitive bases. Synthesis of oligonucleotides carrying $\mathrm{O}^{4}$-alkylthymidines and 5-azacytidine

The carcinogenicity of $N$-nitroso alkylating agents such as nitrosoureas and nitrosoamines is believed to be mediated by alkylation of DNA nucleobases, in particular $O^{6}$-alkylguanine and $O^{4}$-alkylthymine. To study the biological role of $O^{4}$ alkylthymine residues in DNA, it was important to develop procedures for incorporating these lesions in synthetic DNA. These compounds are difficult to incorporate as they are very sensitive to the ammonia used for deprotecting the synthetic DNA (Singer et al., 1978) that yields 5-methylcytosine derivatives (Fig. 5a). For those oligonucleotides carrying $\mathrm{O}^{4}$-methylthymine this obstacle was overcome by using methoxide ions (methanol and 1,8-diazabiciclo[5.4.0]undec-7-ene, DBU), which removed the baseprotecting groups (Fig. 5b, Li et al., 1987, Borowy-Borowsky and Chambers, 1989). This strategy was extended to oligonucleotides carrying $O^{4}$-ethyl, $O^{4}$-propyl (Roelen et al., 1992) and $O^{4}$-benzylthymine (Fábrega et al., 1995) when more labile groups, such as phenoxyacetyl or t-butylphenoxyacetyl, were used to protect nucleobases. In this way, the lower nucleophilicity of the corresponding alcoxide ions can be offset. However these methods proved ineffective for other $\mathrm{O}^{4}$-alkylthymine residues. 


\section{Figure 5}

A more general method for the preparing oligonucleotides that carry $\mathrm{O}^{4}$-alkylthymines was thus proposed (Fernández-Forner et al., 1990). In this method, the ( $p$ nitrophenyl)ethyl and the (p-nitrophenyl)ethoxycarbonyl (NPE, NPEOC) groups (Himmelsbach et al., 1984) were used to protect natural nucleosides. Developed by Pfleiderer's group (Pfleiderer et al., 1986), these groups are removed by a $\beta$-elimination mechanism, which is carried out under non-nucleophilic conditions suitable for the integrity of $\mathrm{O}^{4}$-alkylthymine residues. This method has been successfully used for the preparation of oligonucleotides carrying $O^{4}$-ethyl (Fernández-Forner et al., 1990), $O^{4}$ propyl (Eritja et al., 1992), and $O^{4}$-butylthymine (Aviñó et al., 1995).

During development of this procedure we found that short oligonucleotides of good purity could be obtained but that those longer than 10 bases contained several impurities and exhibited low yield. One cause of these problems stemmed from base alkylation by acrylonitrile, formed during the removal of the cyanoethyl phosphate protecting group (Eritja et al., 1992). The use of the less reactive ( $p$-nitrophenyl)ethyl phosphate group and/or(?) the utilization of thymine as scavenger in the deprotection solution minimized base alkylation such that longer and cleaner oligonucleotides could be obtained under conditions compatible with ammonia-sensitive compounds (Aviñó and Eritja, 1994).

A second problem was the stability of both the succinyl and the (o-nitrophenyl)ethyl linkages (Eritja et al., 1992) to DBU solutions. Although these linkages are reportedly labile to DBU, we observed that the cleavage efficiency of oligonucleotides on these supports were length- and sequence-dependent and that thymine-rich oligonucleotides were released from supports in very low yields (Aviñó et al., 1996). The use of the more labile oxalyl (Alul et al., 1991) linker and thymine as scavenger employing NPE 
protection provided the best results when preparing oligonucleotides carrying ammoniasensitive moieties (Aviñó et al., 1996). When compared with standard amide protection this method is less efficient and requires the preparation of protected monomers that are not commercially available. Despite such inconveniences, it provides modified oligonucleotides that cannot be obtained through standard procedures.

A clear example of the application of this method in the preparing oligonucleotides that carry highly sensitive nucleobases was the synthesis of oligonucleotides carrying 5azacytosine residues (Güimil García, R. et al., 2001). 5-Azacytosine is a cytosine analog in which the carbon at position 5 of the pyrimidine ring is replaced by a nitrogen atom. Both ribonucleoside and 2'-deoxyribonucleoside are potent cytotoxic agents used for the treatment of several cancer types with varying degrees of success. As result of their incorporation into DNA, these drugs can demethylate DNA using a unique mechanism of action that affects gene regulation. To elucidate the molecular basis underlying their inhibitory properties, we needed to synthesize oligonucleotides carrying this base. However the triazine ring's instability to ammonia precluded the use of standard phosphoramidite protocols. Thus, these modified oligonucleotides could only be prepared using the NPE and NPEOC groups to protect the exocyclic amino functions. These groups could then be removed under conditions that were not detrimental to the integrity of the 5-azacytosine ring (Güimil García, R. et al., 2001).

\section{Non-radioactive labelling and oligonucleotides as specific inhibitors of gene expression}

Recent advances in DNA techniques have led to the widespread use of specific nucleic acid hybridization probes as an alternative methodology for detecting human infectious diseases. Polymerase Chain Reaction (PCR) has increased the clinical uses of DNA- 
based diagnostic tests by producing sufficient target sequences such that simple methods can be used to identify pathogens from crude DNA preparations (Mullis et al., 1986). In parallel, a large effort has been undertaken to develop non-radioactive DNA labelling systems and immobilization methods for handling large numbers of samples. In the oligonucleotide field, these applications have triggered the development of nucleosidic and non-nucleosidic phosphoramidite derivatives for the functionalization of oligonucleotides. Indeed, these derivatives have permitted the efficient preparation of oligonucleotides carrying fluorescent compounds, biotin, enzymes as well as intercalating, and DNA cleaving groups (Goodchild, 1990).

At the same time, short oligonucleotides were shown to be useful for the selective inhibition of gene expression (Zamecnik and Stephenson, 1978). To achieve the desired inhibition, antisense oligonucleotides complementary to target mRNA should penetrate inside the cells and bind to their complementary sequence before exonuclease activity degrades them. A large variety of modified oligonucleotides have been designed to enhance nuclease resistance. The synthesis and applications of modified oligonucleotides as inhibitors of gene expression has been extensively reviewed (Agrawal, 1993 and 1994, Braasch and Corey, 2002, Crooke and Lebleu, 1993, Thuong and Helene, 1993, Uhlmann and Peyman, 1990, Sproat, 1995). One alternative to antisense oligonucleotides are the short interfering double-stranded RNA molecules (siRNA, Elbashir et al., 2001 and Achenback et al., 2003) that can be used to inhibit expression of a particular gene by degrading its mRNA using RNA interference machinery (Craig and Mello, 1998).

Synthesis of oligonucleotide-peptide conjugates 
Covalent attachment of poly(L-Lysine) to oligonucleotides enhanced the inhibitory properties of oligonucleotides (Lemaitre, 1987) by improving cellular uptake. This led us to study the use of peptide sequences for in vivo targeting of antisense oligonucleotides. Among the first peptide sequences studied were nuclear localization sequences (NLS, Fig. 6, Eritja et al., 1991), which are rich in lysines.

\section{Figure 6}

The preparation of oligonucleotide-peptide conjugates poses an interesting challenge since the conventional protection schemes are not compatible. For example, amide-type protecting groups are used to protect nucleobases. These protecting groups are removed by ammonia under conditions that could hydrolyze peptide bonds or cause unwanted side-reactions such as racemization or aspartimide formation. However, all standard protection schemes in solid-phase peptide synthesis use acid treatments which could cause partial depurination of DNA. Two different strategies that overcome these problems have been described: 1) the post-synthetic conjugation approach (Fig. 6, Eritja et al., 1991); and 2) the stepwise solid-phase synthesis approach (Fig. 7, de la Torre et al., 1994 and 1999). The synthesis and applications of oligonucleotide-peptide conjugates has been extensively reviewed (Eritja, 2000, Tung and Stein, 2000, Gait, 2003, Grandas et al., 2004, Venkatesan et al., 2006).

\section{Figure 7}

In the post-synthetic conjugation approach, although the oligonucleotide and the peptide are built in a separate support using standard protocols, they are conveniently 
functionalised for linkage following synthesis. In the stepwise solid-phase approach the oligonucleotide-peptide conjugate is prepared in a single support using special protecting groups and modified protocols that minimize unwanted side-reactions (de la Torre et al., 1994 and 1999). In a comparative study we demonstrated that both methodologies yielded similar results during the preparation of oligonucleotides carrying NLS sequences (de la Torre et al., 1999, Eritja, 2000). We believe that the post-synthetic conjugation approach is the best choice for preparing small amounts of oligonucleotide-peptide conjugates in which the peptide portion is a protein or a large peptide. The stepwise solid-phase approach will be useful in preparing large amounts of conjugates carrying short peptide sequences. Oligonucleotide-peptide conjugates carrying nuclear localization sequences have been prepared by several authors (Eritja et al., 1991, de la Torre et al., 1999, Reed et al., 1995, Zanta et al., 1999). Oligonucleotides complementary to the mRNA of calmodulin carrying NLS sequences were found inactive in the freshwater ciliate Paremecium (Reed et al., 1995). A single nuclear localization signal sequence in a 3.3-kbp luciferase gene has been shown to greatly enhance transfection (Zanta et al., 1999). We also studied the effects of the peptide sequence upon the binding properties of oligonucleotides, especially vis-à-vis mismatch discrimination. To this end, oligonucleotides complementary to a mutated Ha-ras oncogene (Duroux et al., 1995) carrying NLS sequences were prepared (de la Torre et al., 1999). These oligonucleotide-peptide conjugates hybridized with complementary sequences possessing a slightly higher stability than unmodified sequences. This is consistent with the results obtained with conjugates carrying basic amino acids (Zhu et al., 1993, Harrison and Balasubramanian, 1998, Marchán et al. 2004). However, the binding of conjugates carrying nuclear localization sequences to the target 27-mer RNA proved 10-fold less efficient (de la Torre et al., 1999). However, 
despite their less efficient binding, conjugates carrying the nuclear localization sequence can distinguish single-mutated RNA from wild-type RNA (de la Torre et al., 1999).

Oligonucleotides carrying the somatostatin analog, Tyr3-octreotate, were prepared (Mier et al., 2000). Somatostatin is a cyclic tetradecapeptide found in the hypothalamus that exerts inhibitory effects on the secretion of growth hormones. Octreotide is a cyclic octapeptide derived from somatostatin boasting an improved specificity. Somatostatin receptors are overexpressed by a variety of neoplastic tissues, especially endocrine tumors. The introduction of octreotate into oligonucleotides is designed to increase the uptake of anticancer oligonucleotides by tumor cells. Oligonucleotide phosphorothioates carrying octreotate were prepared by post-synthetic conjugation. An octreotate derivative with a maleimido group at the $\mathrm{N}$-terminal position was place in reaction with a thiol-oligonucleotide to obtain the desired conjugates. The resulting conjugates exhibited both a high binding affinity to somatostatin receptors and good hybridisation properties (Mier et al., 2000). Nevertheless, in vivo cellular uptake, as well as accumulation in tumor tissues, proved better using the peptide nucleic acid (PNA, Hyrup and Nielsen 1996, Uhlmann et al., 1998) derivative instead of the phosphorothioate (Mier et al., 2003).

Moreover, we have attempted to introduce peptide sequences into oligonucleotides as a type of non-radioactive labelling system. Although this is more difficult than introducing other non-radioactive labels such as biotin, fluorescein, or digoxigenin, the great diversity of antibodies raised against peptides led us to consider oligonucleotidepeptide conjugates as an alternative labelling system of great potential, particularly in multiple hybridisation experiments. To test these possibilities we prepared oligonucleotides carrying a c-myc tag-sequence (Gottschling et al., 1998). In preparing the oligonucleotide-peptide conjugates we used both the post-synthetic conjugation 
(Gottschling et al., 1998) and stepwise approaches (Frieden et al., 2004). The conjugates were recognized by an anti-c-myc monoclonal antibody while detection was achieved through interaction with a peroxidase-conjugated antibody and a chemiluminescent substrate, as well as with gold-labeled antibody and inductively coupled plasma - mass spectrometry (ICPMS) (Merkoçi et al., 2005). Similarly, peptide nucleic acids (PNA) were labelled by the addition of the same c-myc peptide sequence (Gottschling et al., 2000). The resulting conjugates exhibited a higher affinity to complementary DNA than unmodified oligonucleotides (Gottschling et al., 2000).

In the stepwise approach, oligonucleotide-peptide conjugates are prepared by stepwise addition of amino acids and nucleobases in solid phase on the same solid support. This is usually performed by first assembling the peptide using t-butoxycarbonyl (Boc) protected amino acids with base labile groups such as fluoren-9-ylmethyl (Fm), fluoren9-ylmethoxycarbonyl (Fmoc), and trifluoroacetyl (TFA) groups to protect side chains. Although these protocols generate oligonucleotide-3'-peptide, they could not be used to incorporate peptides at the 5' end or in the middle of the oligonucleotide sequence. Recently, a method for the solid-phase synthesis of oligonucleotide-5'-peptide conjugates has been described. It is based on the use of the 2-(biphenyl-4-yl)propan-2yloxycarbonyl (Bpoc) group for the protection of the $\alpha$-amino group (Zaramella et al., 2004). These groups can be removed under mildly acidic conditions suitable for DNA. In addition, we have developed an efficient method to synthesize short oligonucleotide5'-peptide conjugates via stepwise synthesis using commercially available Fmocprotected amino acids (Ocampo et al., 2005). Although the Fmoc-removal conditions are not orthogonal to the base-labile cyanoethyl protection of DNA phosphotriester moieties, we found that the presence of unprotected phosphate groups did not hinder the assembly of small peptide sequences on oligonucleotide supports. Those groups labile 
to mild acidic conditions (such as $1 \%$ trifluoroacetic acid) were used to protect side chains of $\mathrm{N}^{\alpha}$-Fmoc-protected amino acid side chains (Ocampo et al., 2005).

\section{Triplex-stabilizing properties of 8-aminopurines}

Oligonucleotides can interact in a sequence-specific manner to homopurinehomopyrimidine sequences of duplex and single-stranded DNA and RNA to form triplexes (Thuong and Hélène, 1993). Nucleic acid triplexes have potential applications in diagnostics, gene analysis, and therapy (Thuong and Hélène, 1993, Soyter and Potoman, 1996, Vasquez and Glazer, 2002, Robles et al., 2002) Depending on the composition and orientation of the third strand vis-à-vis the central homopurine Watson-Crick strand, triplexes are classified into two main categories: (i) parallel and (ii) antiparallel (Thuong and Hélène, 1993).

The most-well characterized parallel triplex is the one formed between a doublestranded homopurine-homopyrimidine helix (duplex DNA) and a single-stranded homopyrimidine track (triplex-forming oligonucleotide). In this type of triple helix, the triplex-forming oligonucleotide binds to the major groove (parallel to the homopurine strand of Watson-Crick double-helical DNA) via Hoogsteen hydrogen bonding, and is stabilized under acidic conditions.

In the antiparallel triplexes, the third strand composed of purine bases binds _in a $\mathrm{pH}$ independent and antiparallel fashion to the homopurine duplex strand via reverseHoogsteen hydrogen bonds.

The introduction of an amino group at position 8 of the Watson-Crick purines (A, G and hypoxanthine, Fig. 8) produces a high stabilization of parallel triplexes (Kamai et al., 1998, Güimil-García et al., 1998, Güimil-García et al., 1999, Soliva et al., 2000, Soliva et al., 2001). While the stabilizing properties of these analogues were hypothesized 
some thirty ago (Hattori et al., 1975 and 1976), experimental data was not then available due to self-aggregation of homopolymers containing these bases. Recently, the preparation of oligonucleotides carrying 8-aminopurines was described and a high stabilization effect on triplex was found (Kamai et al., 1998, Güimil-García et al., 1998, Güimil-García et al., 1999, Soliva et al., 2000, Soliva et al., 2001). The triplexstabilization properties of the amino group at position 8 results from a combined effect of the gain of one Hoogsteen purine-pyrimidine H-bond (Fig. 8) and the propensity of the amino group to be integrated into the 'spine of hydration' located in the minormajor groove of the triplex (Güimil-García et al., 1998).

\section{Figure 8}

Sequence-specific triple-helix structures can also be formed by DNA clamps. Parallelstranded DNA clamps consist of purine residues linked to a homopyrimidine chain of inverted polarity by 3'-3' or 5'-5' internucleotide junctions (Fig. 9, van de Sande et al., 1988), which interact with single-stranded homopyrimidine nucleic acid targets (Kandimalla and Agrawal, 1996). In this type of triplex, the clamp homopurine strand binds the homopyrimidine target through Watson-Crick bonds whereas the clamp homopyrimidine strand, which binds via Hoogsteen bonding, is stabilized under acidic conditions. The stability of triple helices has been enhanced by replacing natural bases

with some modified bases such as 8-aminopurine residues (Aviñó et al., 2001, Aviñó et al., 2002, Aviñó et al., 2004). Their presence has also stabilized Hoogsteen parallelstranded duplex structure (Aviñó et al., 2001, Cubero et al., 2002). 


\section{Figure 9}

This same strategy has been proven to generate stable antiparallel triplexes using purine-rich clamps as templates (i.e. antiparallel-clamps). Antiparallel clamps formed by a G,A- or G,T-Hoogsteen sequence linked to a polypurine sequence carrying 8aminopurines have also been prepared (Aviñó et al., 2003) and shown to form more stable triplexes if 8-aminoguanine is present in the purine Watson-Crick position. The presence of 8-aminoadenine only acted as stabilizing agent in antiparallel clamps carrying G,T-Hoogsteen strand (Aviñó et al., 2003).

The increased binding properties of clamps carrying 8-aminopurines may be of special interest for the development of applications based on triple-helix formations. One of the first such to be studied involved capture of the cauliflower mosaic virus 35S promoter sequence by 8-aminopurine oligonucleotide clamps (Nadal et al. 2005). The presence of this sequence serves as a marker for genetically modified organisms (GMO) in food. The cauliflower mosaic virus 35S promoter sequence features a 12-base polypyrimidine target. Binding of oligonucleotide clamps was prevented by the target's secondary structure. This problem was solved with a new strategy based on the addition of a tail sequence to a Watson-Crick strand such that modified clamps were able to form triple helices with structured DNA or RNA molecules. This tail-clamp strategy was shown to overcome structural interferences, while simultaneously increasing the stability of triplex formation to a high degree.

A similar result was found during the development of capture probes for the detection of bacteria on food. We synthesized parallel tail-clamps designed to bind with Listeria innocua iap mRNA sequences containing a polypyrimidine track (Nadal et al., 2006). Our aim was to obtain optimum conditions for the triplex affinity capture of Listeria 
innocua iap mRNA sequences in order to develop new detection methods for pathogens based on the specific identification of their nucleic acids. In our study, we explored the

effects of $\mathrm{pH}$ on the interaction of parallel tail-clamps with their target by UV thermal melting analysis. In addition, we optimized a triplex affinity capture assay capable of recovering iap mRNA molecules from a total RNA solution purified from $L$. innocua cells in a sequence-specific manner. Optimal results were obtained with tail-clamps carrying 8-aminoadenine moieties under neutral $\mathrm{pH}$ conditions: $45 \%$ of the iap mRNA molecules from a total RNA solution were captured (Nadal et al., 2006).

\section{Synthesis of oligonucleotides for use in the assembly of nanomaterials.}

There is a considerable interest in the assembly properties of biopolymers for the construction of nanomaterials. In this way, synthetic oligonucleotides have been used as templates for the assembly of inorganic nanocrystals, especially gold nanoparticles (Mirkin et al., 1996, Alivisatos et al., 1996). The hybridization properties of the oligonucleotides allow for the assembly of gold nanoparticles in dimensions based on the length of the oligonucleotides (Mirkin et al., 1996) and the formation of threedimensional networks (Alivisatos et al., 1996) that have special optical properties used for monitoring DNA hybridization (Storhoff et al., 1999). Oligonucleotides designed to form cruciform structures have been used to produce two-dimensional networks (Seeman, 2003, Seeman and Lukerman, 2005). In addition, the fabrication of metal nanowires templated by DNA has been described (Braun et al., 1998). DNA from one phage was fixed between two gold electrodes $(12-16 \mu \mathrm{m})$ using short oligonucleotides immobilized to the electrodes by thiol groups. The building of a silver nanowire was achieved by binding silver ions to phosphate groups of DNA and using a reducing agent to convert the silver ions to silver (Braun et al., 1998). 
A flexible method for the fabrication of gold nanostructures using oligonucleotide derivatives

From the fabrication of the first chips in the 1950s to the present the density of the functional units per surface unit has doubled every 3-4 years. This has been possible thanks to technological advances that allowed for the miniaturization of circuits. However, the actual technologies derived from photolithography are reaching their physical limits while, conversely, chemists and biologists are working with larger and larger biomolecules. For these reasons, it is believed that in the near future, circuitry may be prepared using biomolecules that will order the nanomaterials in solution. The resulting structures will then be settled into the spaces produced by photolithography.

One promising biomolecule is DNA since it forms lineal structures composed of two strands with known self-assembling properties. Moreover, there is a solid methodology to prepare DNA strands up to 100 bases (about $30 \mathrm{~nm}$ of length).

In particular, we were interested in the preparation of synthetic DNA derivatives designed to assemble a molecular wire between two or three gold electrodes, which are needed to address individual nanoparticles from macroscopic electrodes (Iacopino et al., 2003, Ongaro et al., 2004, Stanca et al., 2005, Stanca et al., 2006). Synthetic oligonucleotides were used to prepare the molecular wires, offering the possibility to introduce modifications at any predetermined position.

The proposed structure for the simplest target molecule consists of three elements having different roles: anchoring, extension, and recognition (Fig. 10). Two anchoring elements are located at each end, both having disulfide groups allowing the wires to be attached to the electrodes. The center of the structure is a chimeric compound with a DNA segment that positions the element in the middle of the structure. It also contains 
biotin as a recognition group, isolated from the DNA by a spacer molecule made of two hexaethylenglycol units. This recognition element is used to direct a nanoparticle into the middle of the structure as well as to connect the two branches. The size of the whole structure is determined by the extension elements between the recognition and the anchoring elements.

\section{Figure 10}

The extension elements (100 bases long) were prepared using protocols to produce long oligonucleotides while thiolated oligonucleotides were prepared using standard protocols (de la Torre et al., 2002). Special protocols were developed for the preparation of the recognition elements since the polarity of the DNA strands is reversed in the middle of the molecule, thereby providing symmetry to the central assembly. The twoarmed recognition element was prepared by sequentially adding 10 different phosphoramidites. Starting from the 3'-end, the first half of the sequence was assembled using the four standard phosphoramidites. Subsequently, hexaethyleneglycol and biotintetraethyleneglycol phosphoramidites were added. Finally, the second half of the molecule was assembled using the four reversed phosphoramidites (Grimau et al., 2003). Synthesis of the oligonucleotides carrying three branches was conducted in similar fashion although a symmetric branching molecule was added. First, the 20 mer sequence was built in the $3^{\prime}->5$ ' direction using standard phosphoramidites and the hexaethyleneglycol phosphoramidite. Then, the biotin-tetraethyleneglycol was added. Afterwards, a symmetric branching phosphoramidite was added to the sequence. Finally, the rest of the desired sequence was assembled in the 5'->3' direction using reversed phosphoramidites and the hexaethyleneglycol phosphoramidite (Grimau et al., 2003). 
Using these oligonucleotides the DNA-templated assembly of a protein-functionalized $10 \mathrm{~nm}$ gap electrode, from suitably modified gold nanoparticles on a silicon wafer substrate, was achieved (Ongaro et al., 2004, Stanca et al., 2005, Stanca et al., 2006). This protein-functionalized electrode was recognized and selectively bound by a suitably modified gold nanoparticle that was localized in the $10 \mathrm{~nm}$ gap (Ongaro et al., 2004, Stanca et al., 2005, Stanca et al., 2006). These findings are of interest for the fabrication of next-generation electronic devices.

\section{Concluding remarks}

Bruce Merrifield’s comments in his 1984 Nobel Lecture (“It soon become clear to me that ... a new approach was needed if large numbers of peptides or if larger and more complex peptides were to be made”) are clearly applicable to oligonucleotide synthesis. At that time I began to work in this field, oligonucleotides synthesis that was becoming the robust method that is today. Efficient methods have been developed to produce a large variety of oligonucleotides and oligonucleotide-related derivatives that today are being used for a wide array of applications. In this review some of the developments in this field are described. The paradigm introduced by Merrifield's visionary work is the production of large microarrays of oligonucleotides. A photolithographic system, in tandem with a light-sensitive group for the temporary protection of the 5'-hydroxyl allows for the massive, parallel synthesis of large numbers of oligonucleotide sequences on a surface, which following deprotection are ready for hybridization with complementary sequences. The actual methodology used for the production of these arrays can incorporate millions of oligonucleotides, enough to cover nearly an entire chromosome sequence, on a single chip. All these of developments only became possible after the introduction of solid-phase synthesis by Merrifield. 
Acknowledgements. The work summarized in this review has been conducted by a large number of colleagues and collaborators whom I thank for their contributions and friendship. We also thank E.E.C.C., E.M.B.L., the Spanish Ministry of Education and the Fundació La Caixa for funding this work.

\section{References}

Acedo. M., Fàbrega, C., Aviñó, A. et al. (1994) A simple method for N-15 labelling of exocyclic amino groups in synthetic oligodeoxynucleotides. Nucleic Acids Res. 22, 2982-2989.

Acedo, M., De Clercq, E. and Eritja, R. (1995) Synthesis and biophysical and biological properties of oligonucleotides containing 2-aza-2'-deoxyinosine. J. Org. Chem. 60, 6262-6269.

Achenbach, T.V., Brunner, B. and Heermeier, K. (2003) Oligonucleotide-based knocdown technologies: antisense versus RNA interference. ChemBioChem 4, 928-935.

Agrawal, S. (1993). Protocols for oligonucleotides and analogs. Synthesis and properties. Methods in Mol. Biol. Vol 20, Humana Press Inc., Totowa, NJ.

Agrawal, S. (1994). Protocols for oligonucleotide conjugates. Synthesis and analytical techniques. Methods in Mol. Biol. Vol 26, Humana Press Inc., Totowa, NJ. 
Alivisatos, A.P., Johnsson, K.P., Peng, X. et al. (1996) Organization of nanocrystal molecules using DNA. Nature 382, 609-611.

Aviñó, A. and Eritja, R. (1994) Use of Npe-protecting groups for the preparation of oligonucleotides without using nucleophiles during the final deprotection. Nucleosides Nucleotides 13, 2059-2069.

Aviñó, A., Güimil-Garcia, R., Marquez, V.E. and Eritja, R. (1995) Preparation and properties of oligodeoxynucleotides containing 4-O-butylthymine, 2fluorohypoxanthine and 5-azacytosine. Bioorg. Med. Chem. Lett., 5, 2331-2336.

Aviñó, A., Güimil García, R., Díaz, A., Albericio, F. and Eritja, R. (1996) A comparative study of supports for the synthesis of oligonucleotides without using ammonia. Nucleosides Nucleotides 15, 1871-1889.

Aviñó, A., Morales, J.C., Frieden, M. et al. (2001) Parallel-stranded hairpins containing 8-aminopurines. Novel efficient probes for triple-helix formation. Bioorg. Med. Chem. Lett. 11, 1761-1763.

Aviñó, A., Frieden, M., Morales, J.C. et al. (2002) Properties of triple helices formed by parallel-stranded hairpins containing 8-aminopurines. Nucleic Acids Res. 30, 26092619. 
Aviñó, A., Cubero, E., González, C., Eritja, R. and Orozco, M. (2003) Antiparallel triple helices. Structural characteristics and stabilization by 8-amino derivatives. J. Am. Chem. Soc. 125, 16127-16138.

Aviñó, A., Grimau, M.G., Frieden, M. and Eritja, R. (2004) Synthesis and triple-helix stabilization properties of branched oligonucleotides carrying 8-aminoadenine moieties. Helv. Chim. Acta 87, 303-316.

Basu, A.K. and Essigmann, J.M. (1988) Site-specifically modified oligodeoxynucleotides as probes for the structural and biological effects of DNAdamaging agents. Chem. Res. Toxicol. 1, 1-18.

Beaucage, S.L. and Caruthers, M.H. (1981) Deoxynucleoside phosphoramidites- a new class of key intermediates for deoxypolynucleotide synthesis. Tetrahedron Lett. 22, 1859-1862.

Beaucage, S.L. and Iyer R.P. (1992) Advances in the synthesis of oligonucleotides by the phosphoramidite approach. Tetrahedron 48, 2223-2311.

Beaucage, S.L. and Iyer R.P. (1993a) The functionalization of oligonucleotides via phosphoramidite derivatives. Tetrahedron 49, 1925-1963.

Beaucage, S.L. and Iyer, R.P. (1993b) The synthesis of modified oligonucleotides by the phosphoramidite approach and their applications. Tetrahedron 49, 6123-6194. 
Beaucage, S.L. and Iyer, R.P. (1993c) The synthesis of specific ribonucleotides and unrelated phosphorylated biomolecules by the phosphoramidite method. Tetrahedron 49, 10441-10488.

Beechem, J.M., Otto, M.R., Bloom, L.B. et al. (1998) Exonuclease-polymerase active site partitioning of primer-template DNA strands and equilibrium $\mathrm{Mg}^{2+}$ binding properties of bacteriophage T4 polymerase. Biochemistry 37, 10144-10155.

Benner, S.A. (2004) Understanding nucleic acids using synthetic chemistry. Acc. Chem. Res. 37, 784-797.

Bloom, L., Otto, M.R., Eritja, R., Reha-Krantz, L., Goodman, M.F. and Beechem, J.M. (1994) Pre-steady-state kinetic analysis of sequence-dependent nucleotide excision by the 3'-exonuclease activity of bacteriophage T4 DNA polymerase. Biochemistry, 33, 7576-7586.

Borowy-Borowski, H. and Chambers, R.W. (1989) Solid-phase synthesis and side reactions of oligonucleotides containing O-alkylthymine residues. Biochemistry 28, $1471-1477$

Braasch, D.A. and Corey, D.R. (2002) Novel antisense and peptide nucleic acid strategies for controlling gene expression. Biochemistry 41, 4503-4510.

Braun, E., Eichen, Y., Sivan, U. and Ben-Yoseph, G. (1998) DNA-templated assembly and electrode attachment of a conducting silver wire. Nature 391, 775-778 
Caruthers, M.H., Barone, A.D., Beaucage, S.L. et al. (1987) Chemical synthesis of deoxyoligonucleotides by the phosphoramidite method. Methods Enzymol. 154, 287313.

Connolly, B.A. (1992) Synthetic oligodeoxynucleotides containing modified bases. Methods Enzymol. 211, 36-53.

Crooke, S.T. and Lebleu, B., (1993). Antisense Research and Applications. CRC Press Inc., Boca Raton, Florida.

Cubero, E., Güimil García, R., Luque, F.J., Eritja, R. and Orozco, M. (2001) The effect of amino groups on the stability of DNA duplexes and triplexes based on purines derived from inosine. Nucleic Acids Res. 29, 2522-2534.

Cubero, E., Aviñó, A., de la Torre, B.G. et al. (2002) Hoogsteen-based parallel-stranded duplexes of DNA. The effect of 8-amino derivatives. J. Am. Chem. Soc. 124, 31333142.

De la Torre, B.G., Aviñó, A., Tarrason, G., Piulats, J., Albericio, F. and Eritja, R., (1994) Stepwise solid-phase synthesis of oligonucleotide-peptide hybrids. Tetrahedron Lett. 35, 2733-2736. 
De la Torre, B.G., Albericio, F., Saison-Behmoaras, E., Bachi, A. and Eritja, R. (1999) Synthesis and binding properties of oligonucleotides carrying nuclear localization sequences. Bioconjugate Chem. 10, 1005-1012.

De la Torre, B.G., Morales, J.C., Aviñó, A. et al. (2002) Synthesis of oligonucleotides carrying anchoring groups and their use in the preparation of oligonucleotide-gold conjugates. Helv. Chim. Acta 85, 2594-2607.

Duroux, I., Godard, G., Boidot-Forget, M., Schwab, G., Hélène, C. and SaisonBehmoaras, T. (1995) Rational design of point mutation-selective antisense DNA targeted to codon 12 of Ha-ras mRNA in human cells. Nucleic Acids Res. 23, 34113418.

Elbashir, S.M., Harborth, J., Lendeckel, W., Yalcin, A., Weber, K. and Tuschl, T. (2001) Duplexes of 21-nucleotide RNAs mediate RNA interference in cultured mammalian cells. Nature 411, 494-498.

Eritja, R., Kaplan, B.E., Mhaskar, D., Sowers, L.C., Petruska, J. and Goodman, M.F. (1986a) Synthesis and characterization of defined oligomers containing 2-aminopurine. Nucleic Acids Res. 14, 5869-5884.

Eritja, R., Horowitz, D.M., Walker, P.A. et al. (1986b) Synthesis and properties of oligonucleotides containing 2'-deoxynebularine and 2'-deoxyxanthosine. Nucleic Acids Res. 14, 8135-8153. 
Eritja, R., Pons, A., Escarceller, M., Giralt, E. and Albericio, F. (1991) Synthesis of defined peptide-oligonucleotide hybrids containing a nuclear transport signal sequence. Tetrahedron 47, 4113-4120.

Eritja, R., Robles, J., Aviñó, A., Albericio, F. and Pedroso, E. (1992) A synthetic procedure for the preparation of oligonucleotides without using ammonia and its application for the synthesis of oligonucleotides containing O-4-alkyl thymidine. Tetrahedron 48, 4171-4182.

Eritja, R. (2000) Synthesis of oligonucleotide-peptide conjugates and nucleopeptides in Solid-phase synthesis. A practical guide, Kates, S.A. and Albericio, F., Eds. Marcel Dekker Inc., New York, 529-548.

Fàbrega, C., Eritja, R., Sinha, N.D., Dosanjh, M.K. and Singer, B. (1995) Synthesis and properties of oligonucleotides containing the mutagenic base $\mathrm{O}^{4}$-benzylthymidine. Bioorg. Med. Chem. 3, 101-108

Fagan, P.A., Fabrega, C., Eritja, R., Goodman, M.F. and Wemmer, D.E. (1996) NMR study of the conformation of the 2-aminopurine:cytosine mismatch in DNA. Biochemistry 35, 4026-4033.

Fernández-Forner, D., Palom, Y., Ikuta, S., Pedroso, E. and Eritja, R. (1990) Synthesis and characterization of oligonucleotides containing the mutagenic base analogue 4-Oethylthymidine. Nucleic Acids Res. 18, 5729-5734. 
Fernández-Forner, D., Eritja, R., Bardella, F. et al. (1991) Preparation of oligonucleotides containing dAICA using an unexpected side-reaction observed on a protected derivative of 2-aza-2'-deoxyinosine. Tetrahedron 47, 8917-8930.

Fire, A., Xu, S., Montgomery, M.K., Kostas, S.A., Driver, S.E. and Mello, C.C., (1998) Potent and specific genetic interference by double-stranded RNA in Caenorhabditis elegans. Nature 391, 806-811.

Frieden, M., Aviñó, A., Tarrasón, G., Escorihuela, M., Piulats, J. and Eritja, R., (2004) Synthesis of oligonucleotide-peptide conjugates carrying the c-myc peptide epitope as recognition system. Chem. Biodiv., 1, 930-938.

Fujimoto, J., Nuesca Z., Mazurek, M. and Sowers, L.C. (1996) Synthesis and hydrolysis of oligodeoxyribonucleotides containing 2-aminopurine. Nucleic Acids Res. 24, 754759.

Gait, M.J. (1985). Oligonucleotide synthesis. A practical approach. IRL Press, Oxford.

Gait, M.J. (2003) Peptide-mediated cellular delivery of antisense oligonucleotides and their analogues. Cell. Mol. Life Sci. 60, 844-853.

Gargallo, R., Vives, M., Tauler, R. and Eritja, R. (2001) Protonation studies and multivariate curve resolution on oligodeoxynucleotides carrying the mutagenic base 2aminopurine. Biophys. J. 81, 2886-2896. 
Giralt, E., Eritja, R. and Pedroso, E. (1981) Diketopiperazine formation in acetamidoand nitrobenzamido- bridge polymeric supports. Tetrahedron Lett. 22, 3779-3782.

Giralt, E., Eritja, R., Pedroso, E., Granier, C. and vanRietschoten, J. (1986) Convergent solid phase peptide synthesis III. Synthesis of the 44-52 protected segment of the toxin II of Androctonus australis Hector. Tetrahedron 42, 691-698.

Goodchild, J., (1990) Conjugates of oligonucleotides and modified oligonucleotides: A review of their synthesis and properties. Bioconjugate Chem. 1, 165-186.

Gottschling, D., Seliger, H., Tarrasón, G., Piulats, J. and Eritja, R. (1998) Synthesis of oligodeoxynucleotides containing $\mathrm{N}^{4}$-mercaptoethylcytosine and their use in the preparation of oligonucleotide-peptide conjugates carrying c-myc tag sequence. Bioconjugate Chem. 9, 831-837.

Gottschling, D., Seliger, H., Tarrasón, G., Piulats, J., Wiersma, M. and Eritja, R. (2000) Synthesis of peptide nucleic acid-peptide chimeras carrying c-myc TAG-sequence. Lett. Pept. Sci. 7, 35-39.

Grandas, A., Marchán, V., Debéthune, L. and Pedroso, E. (2004) Stepwise solid-phase synthesis of nucleopeptides in Beaucage, S.L., Bergstrom, D.E., Herdewijn, P. Matsuda, A., (Eds), Current protocols in nucleic acid chemistry, John Willey \& Sons, New York, chapter 4.22.1. 
Grimau, M.G., Iacopino, D., Aviñó, A. et al. (2003) Synthesis of branched oligonucleotides as templates for the assembly of nanomaterials. Helv. Chim. Acta 86, 2814-2826.

Güimil-García, R., Bachi, A., Eritja, R., Luque, F.J. and Orozco, M. (1998) Triple helix stabilization properties of oligonucleotides containing 8-amino-2'-deoxyguanosine. Bioorg. Med. Chem. Lett. 8, 3011-3016.

Güimil-García, R., Ferrer. E., Macías, M.J., Eritja, R. and Orozco, M. (1999) Theoretical calculations, synthesis and base-pairing properties of oligonucleotides containing 8-amino-2'-deoxyadenosine. Nucleic Acids Res. 27, 1991-1998.

Güimil García, R., Brank, A.S., Marquez, V.E., Christman J.K. and Eritja, R (2001). Synthesis of oligonucleotide inhibitors of DNA (Cytosine-C5) methyltransferase containing 5-azacytosine residues at specific sites. Antisense Nucleic Acid Drug Dev. 111, 369-378.

Hattori, M., Frazier, J. and Miles, H.T. (1975) Poly(8-aminoguanylic acid): formation of ordered self-structures and interaction with poly(cytidylic acid). Biochemistry 18, 50335045.

Harrison, J.G. and Balasubramanian, S. (1998) Synthesis and hybridization analysis of a small library of peptide-oligonucleotide conjugates. Nucleic Acids Res. 26, 3136-3145. 
Himmelsbach, F., Schulz, B.S., Trichtinger, T., Charubala, R. and Pfleiderer, W. (1984) The $p$-nitrophenylethyl (NPE) group. A versatile new blocking group for phosphate and aglycone protection in nucleosides and nucleotides. Tetrahedron 40, 59-72.

Holz, B., Klimasaukas, S., Serva, S. and Weinhold, E. (1998) 2-Aminopurine as a fluorescent probe for DNA base flipping by methyltransferases. Nucleic Acids Res. 26, 1076-1083.

Hyrup, B. and Nielsen, P. (1996) Peptide nucleic acids (PNA): synthesis, properties and potential applications. Bioorg. Med. Chem. 4, 5-23.

Iacopino, D., Ongaro, A., Nagle, L., Eritja, R. and Fitzmaurice, D. (2003) Imaging the DNA and nanoparticle components of a self-assembled nanoscale architecture. Nanotechnology 14, 447-452.

Kandimalla, E.R. and Agrawal, S. (1996) Hoogsteen DNA duplexes of 3'-3'- and 5'-5'linked oligonucleotides and triplex formation with RNA and DNA pyrimidine single strands: experimental and molecular modelling studies. Biochemistry 35, 15332-15339.

Kawai, K., Saito, I. and Sugiyama, H. (1998) Stabilization of Hoogsteen base pairing by the introduction of NH2 group at the C8 position of adenine. Tetrahedron Lett. 39, 5221-5224.

Khorana, H.G. (1979). Total synthesis of a gene. Science 203, 614-625. 
Kool, E.T. (2001) Hydrogen bonding, base stacking, and steric effects in DNA replication. Annu. Rev. Biophys. Biomol. Struct. 30, 1-22.

Law, S.M., Eritja, R., Goodman, M.F. and Breslauer, K.J. (1996) Spectroscopy and calorimetric characterizations of DNA duplexes containing 2-aminopurine. Biochemistry 35, 12329-12337.

Li, B.F., Reese, C.B. and Swann, R.W. (1987) Synthesis and characterization of oligonucleotides containing O-4-methylthymine. Biochemistry 26, 1086-1093.

Lemaitre, M., Bayard, B. and Leblue, B. (1987) Specific antiviral activity of a poly(Llysine)-conjugated oligodeoxyribonucleotide sequence complementary to vesicular stomatitis virus N protein mRNA initiation site. Proc. Natl. Acad. Sci. USA, 84, 648652.

Letsinger, R.L. and Mahadevan, V. (1965) Oligonucleotide synthesis on a polymer support. J. Am. Chem. Soc. 80, 6212-6222.

Letsinger R.L. and Lunsford W.B. (1976) Synthesis of thymidine oligonucleotides by phosphite triester intermediates. J. Am. Chem. Soc. 98, 3655-3661.

Loakes, D. and Brown, D.M. (1994) 5-Nitroindole as an universal base analogue. Nucleic Acids Res. 22, 4039-4043. 
Loakes, D., Brown, D.M., Linde S. and Hill F. (1995) 3-Nitropyrrole and 5-nitroindole as universal bases in primers for DNA sequencing and PCR. Nucleic Acids Res. 23, 2361-2366.

MacMillan, A.M. and Verdine, G.L. (1991) Engineering tethered DNA-molecules by the convertible nucleoside approach. Tetrahedron 47, 2603-2626.

Marchán, V., Debéthune, L., Pedroso, E. and Grandas, A. (2004) Stabilization of DNA duplexes by covalently-linked peptides. Tetrahedron 60, 5461-5469.

Matteucci, M.D. and Caruthers, M.H. (1981) Nucleotide chemistry. 4. Synthesis of deoxyoligonucleotides on a polymer support. J. Am. Chem. Soc. 103, 3185-3191.

McColum C. and Andrus A. (1991) An optimized polystyrene support for rapid, efficient oligonucleotide synthesis. Tetrahedron Lett. 32, 4069-4072.

McLaughlin, L.W., Leong, T., Benseler, F. and Piel, N. (1988) A new approach to the synthesis of a protected 2-aminopurine derivative and its incorporation into oligodeoxynucleotides containing the Eco-RI and Bam-HI recognition sites. Nucleic Acids Res. 16, 5631-5644.

Merkoçi, A., Aldavert, M., Tarrasón, G., Eritja, R. and Alegret, S. (2005) Toward an ICPMS-Linked DNA assay based on gold nanoparticles immunoconnected through peptide sequences. Anal. Chem. 77, 6500-6503. 
Merrifield, R. B. (1963) Solid phase peptide synthesis I. The synthesis of a tetrapeptide. J. Am. Chem. Soc. 85, 2149-2154.

Michelson, A.M. and Todd, A.R. (1955) Synthesis of a dithymidine dinucleotide containing a 3', 5'-internucleotidic linkage. J. Chem. Soc. 2632-2638.

Mier, W., Eritja, R., Mohammed, A., Haberkorn, U. and Eisenhut, M. (2000) Preparation and evaluation of tumor-targeting peptide-oligonucleotide conjugates. Bioconjugate Chem. 11, 855-860.

Mier, W., Eritja, R., Mohammed, A., Haberkorn, U. and Eisenhut, M. (2003) PeptidePNA conjugates: Targeted transport of antisense therapeutics into tumors. Angew. Chem. Int. Ed. 42, 1968-1971.

Mirkin, C.A., Letsinger, R.L., Mucic, R.C. and Storhoff, J.J. (1996) A DNA-based method for rationally assembling nanoparticles into macroscopic materials. Nature 382, 607-609.

Montserrat, F.X., Grandas, A., Eritja, R. and Pedroso, E. (1994) Criteria for the economic large scale solid-phase synthesis of oligonucleotides. Tetrahedron 50, 26172622.

Mullis, K., Faloona. F., Scharf, S., Saiki, R., Horn, G. and Erlich, H. (1986) Specificenzymatic amplification of DNA in vitro: the polymerase chain reaction. Cold Spring Harbor Symp. Quant. Biol. 51, 263-73. 
Nadal, A., Eritja, R., Esteve, T. and Plà, M. (2005) Parallel- and antiparallel-tail-clamps hairpins increase the efficiency of triplex formation with structured DNA and RNA targets. ChemBioChem 6, 1034-1042.

Nadal, A., Coll, A., Aviñó, A. Esteve, T., Eritja, R. and Plà, M. (2006) Efficient sequence-specific purification of Listeria innocua mRNA species by triplex affinity capture with parallel tail-clamps. ChemBioChem 7, 1039-1047.

Narang, S.A. (1987) Synthesis and applications of DNA and RNA. Academic Press, Orlando.

Nichols, R., Andrews, P.C., Zhang, P. and Bergstrom, D.E. (1994) A universal nucleoside for use at ambiguous sites in DNA primers. Nature 369, 492-493.

Ocampo, S.M., Albericio, F., Fernández, I., Vilaseca, M. and Eritja, R. (2005) A straightforward synthesis of 5'-peptide oligonucleotide conjugates using $\mathrm{N}^{\alpha}$-Fmocprotected amino acids, Org. Lett. 7, 4349-4352.

Ohtsuka, E., Matsuki, S., Ikehara, M., Takahashi, Y. and Matsubara, K. (1985) An alternative approach to deoxyoligonucleotides as hybridisation probes by insertion of deoxyinosine at ambiguous codon positions. J. Biol. Chem. 260, 2605- 2608. 
Ongaro, A., Griffin, F., Nagle, L., Iacopino, D., Eritja, R. and Fitzmaurice, D. (2004) DNA templated assembly of a protein-functionalized nanogap electrode. Adv. Materials $16,1800-1803$.

Pfleiderer, W., Schwarz, M. and Schirmeister, H. (1986) New developments in nucleotide chemistry. Chemica Scripta. 26, 147-154.

Raney, K.D., Sowers, L.C., Millar, D.P. and Benkovic, S.J. (1994) A fluorescencebased assay for monitoring helicase activity. Proc. Natl. Acad. Sci. USA, 91, 66446648.

Reed, M.W., Fraga, D., Schwartz, D.E., Scoller, J. and Hinrichsen, R.D. (1995) Synthesis and evaluation of nuclear targeting peptide-antisense oligodeoxynucleotide conjugates. Bioconjugate Chem. 6, 101-108.

Reese, C.B. (1978) The chemical synthesis of oligo-and poly-nucleotides by the phosphotriester approach. Tetrahedron 34, 3143-3179.

Robles, J., Grandas, A., Pedroso, E., Luque, F.J., Eritja, R. and Orozco, M. (2002) Nucleic acid triple helices: Stability effects of nucleobase modifications. Curr. Org. Chem. 6, 1333-1368.

Roelen, H., Brugge, H.F., van der Elst, H., van der Marel, G.A. and van Boom, J.H. (1992) Solid-phase synthesis of oligodeoxynucleotides containing 4-alkoxythymidine residues. Rcl. Trav. Chim. Pays-Bas, 111, 99-104. 
Schmidt, S. and Cech, D. (1995) A new approach to the synthesis of 2-amino-2'deoxyriboside via tri-n-butyltin hydride reduction. Nucleosides Nucleotides 14, 14451452.

Seela, F. and Debelak, H. (2000) The N8-(2'-deoxyribofuranoside) of 8-aza-7deazaadenine: a universal nucleoside forming specific hydrogen bonds with the four canonical DNA constituents. Nucleic Acids Res. 28, 3224-3232.

Seeman, N.C. (2003) At the crossroads of chemistry, biology, and materials: Structural DNA nanotechnology. Chem. Biol. 10, 1151-1159.

Seeman, N.C. and Lukerman, P.S. (2005) Nucleic acid nanostructures: bottom-up control of geometry on the nanoscale. Rep. Prog. Phys. 68, 237-270.

Singer, B., Kroger, M. and Carrano, M. (1987) $\mathrm{O}^{2}$ - and $\mathrm{O}^{4}$-alkyl pyrimidine nucleosides: stability of the glycosyl bond and of the alkyl group as a function of $\mathrm{pH}$. Biochemistry 17, 1246-1250.

Soliva, R., Güimil García, R., Blas, J.R. et al. (2000) DNA-triplex stabilizing properties of 8-aminoguanine. Nucleic Acids Res. 28, 4531-4539.

Sowers, L.C., Fazakerley, G.V., Eritja, R., Kaplan, B.E. and Goodman, M.F. (1986) Base pairing and mutagenesis: Observation of a protonated base pair between 2- 
aminopurine and cytosine in an oligonucleotide by proton NMR. Proc. Natl. Acad. Sci. USA $83,5434-5438$.

Sowers, L.C., Eritja, R., Kaplan, B.E., Goodman, M.F. and Fazakerley, G.V., (1988) Equilibrium between a wobble and ionised base pair formed between fluorouracil and guanine in DNA as studied by proton and fluorine NMR. J. Biol. Chem. 263, 1479414801.

Sowers, L.C., Goodman, M.F., Eritja, R., Kaplan, B. and Fazakerley, G.V (1989a) Ionized and wobble base-pairing for bromouracil-guanine in equilibrium under physiological conditions. J. Mol. Biol. 205, 437-447.

Sowers, L.C., Eritja, R., Chen, F. et al. (1989b) Characterization of the high pH wobble structure of the 2-aminopurine.cytosine mismatch by N-15 NMR spectroscopy. Biochem. Biophys. Res. Comm. 165, 8135-8153.

Sowers, L.C., Mhaskar, D.N., Khwaja, T.A. and Goodman, M.F. (1989c) Preparation of imino and amino N-15 enriched 2-aminopurine deoxynucleoside. Nucleosides Nucleotides 8, 23-34.

Sowers, L.C., Boulard, Y. and Fazakerley, G.V. (2000) Multiple structures for the 2aminopurine-cytosine mispair. Biochemistry 39, 7613-7620.

Soyter, V.N. and Potaman, V.N. (1996) Triple helical nucleic acids. Springer-Verlag, New York. 
Sproat, B.S. (1995) Chemistry and applications of oligonucleotide analogues J. Biotechnol. 41, 221-238.

Stanca, S.E., Ongaro, A., Eritja, R. and Fitzmaurice, D. (2005) DNA-templated assembly of nanoscale architectures. Nanotechnology 16, 1905-1911.

Stanca, S.E., Eritja, R. and Fitzmaurice, D. (2006) DNA-templated assembly of nanoscale architectures for next-generation electronic devices. Faraday Discus. 131, $155-165$

Storhoff J.J. and Mirkin, C.A. (1999) Programmed materials synthesis with DNA. Chem. Rev. 99, 1849-1862.

Thuong, N.T. and Hélène, C. (1993) Sequence-specific recognition and modification of double-helical DNA by oligonucleotides. Angew. Chem. Int. Ed. Engl. 32, 666-690.

Ti, G.S., Gaffney, B.L. and Jones, R.A. (1982) Transient protection: efficient one-flask syntheses of protected deoxynucleosides. J. Am. Chem. Soc. 104, 1316-1319.

Tung, C.H. and Stein, S. (2000) Preparation of peptide-oligonucleotide conjugates. Bioconjugate Chem. 11, 605-618.

Uhlmann. E. and Peyman, A. (1990) Antisense oligonucleotides: A new therapeutic principle. Chem. Rev. 90, 544-584. 
Uhlmann, E., Peyman, A., Breipohl, G. and Will, D.W. (1998) PNA: Synthetic polyamide nucleic acids with unusual binding properties. Angew. Chem. Int. Ed. 37, 2796-2823.

Van de Sande, J.H., Ramsing, N.B., Germann, M.W. et al. (1988) Parallel stranded DNA. Science 241, 551-557.

Vasquez, K.M. and Glazer, P.M. (2002) Triplex-forming oligonucleotides: principles and applications. Q. Rev. Biophys. 35, 89-107.

Venkatesan, N. and Kim, B. H. (2006) Peptide conjugates of oligonucleotides: Synthesis and applications. Chem. Rev. 106, 3712-3761.

Wright, P., Lloyd, D., Rapp, W. and Andrus, A. (1993) Large scale synthesis of oligonucleotides via phosphoramidite nucleosides and a high-loaded polystyrene support. Tetrahedron Lett. 34, 3373-3376.

Xu, Y.Z., Zheng, Q. and Swann, P.F. (1992) Synthesis of DNA containing modified bases by postsynthetic substitution. Synthesis of oligomers containing 4-substituted thymine, O-4-alkylthymine, 5.methylcytosine, N-4-dimethylamino)-5-methylcytosine and 4-thiothymine. J. Org. Chem. 57, 3839-3845. 
Yu, H., Eritja, R., Bloom, L. B. and Goodman, M.F. (1993) Ionization of Bromouracil and fluorouracil stimulates base pairing frequencies with guanine. J. Biol. Chem. 268, 15935-15943.

Zamecnik P.C. and Stephenson (1978) Inhibition of Rous sarcoma virus replication and cell transformation by a specific oligodeoxynucleotide. Proc. Natl. Acad. Sci. USA 75, 280-284.

Zanta, M.A., Belguise-Valladier, P. and Behr, J.P. 1999 Gene delivery: a single nuclear localization signal peptide is sufficient to carry DNA to cell nucleus. Proc. Natl. Acad. Sci. USA 96, 91-96.

Zaramella, S., Yeheskiely, E. and Stromberg, R. (2004) A method for solid-phase synthesis of oligonucleotide 5'-peptide conjugates using acid-labile alpha-amino protections. J. Am. Chem. Soc., 126, 14029-14035.

Zhu, T., Wei, Z., Tung, C. H. et al. Oligonucleotide-poly-L-ornithine conjugates: binding to complementary DNA and RNA. Antisense Res. Dev. 3, 265-275. 
Figure Legends :

Figure 1: Solid-phase synthesis of oligonucleotides using the phosphoramidite approach. (DMT: dimethoxytrityl, CE: cyanoethyl)

Figure 2: Base-pairing schemes for the mispair between 5-substituted uracil derivatives and guanine; a) wobble base pair, b) ionized base pair, c) base pair involving enol tautomer.

Figure 3: Outline of the preparation of phosphoramidite derivatives used for the synthesis of oligonucleotides carrying 2-aminopurine; a) and b) two methods involving transglycosylation appropriate for the introduction of ${ }^{15} \mathrm{~N}$-labeled 2-aminopurine in oligonucleotides, c) methods involving reduction of guanosine derivatives.

Figure 4: Chemical structures of nucleobases proposed as universal bases by several authors; a: hypoxanthine, b: xanthine, c: 2-azahypoxanthine, d: 8-aminohypoxanthine, e) 3-nitropyrrole, f) 5-nitroindole and g) 8-aza-7-deazaadenine.

Figure 5: Strategies used for preparing oligonucleotides carrying $O^{4}$-alkylythymine; a) the use of ammonia is not possible, unless the R group is sterically hindered, due to the nucleophilic displacement of the alcoxy group yielding 4-methylcytosine; b) oligonucleotides carrying $O^{4}$-methyl, $O^{4}$-ethyl, $O^{4}$-propyl and $O^{4}$-benzylthymines can be prepared using the corresponding alcoxide ions to remove the base protecting groups, c) the use of (p-nitrophenyl)ethyl (NPE) type groups allows the removal of these groups in conditions compatible with ammonia-sensitive molecules. 
Figure 6: Synthesis of oligonucleotide-peptide conjugates by postsynthetic conjugation. The oligonucleotide and the peptide are built in a separate support using standard protocols but they are conveniently functionalized to be linked after synthesis. In this case the use of a maleimido peptide and a thiol-containing oligonucleotide is shown.

Figure 7: Stepwise synthesis of oligonucleotide-peptide conjugates. The oligonucleotide-peptide conjugate is prepared in a single support using special protecting groups and modified protocols that minimize unwanted side-reactions. The scheme shows the synthesis of 3'-peptide oligonucleotide conjugates. The peptide is first assembled using t-butoxycarbonyl (Boc)-protected amino acids with base labile groups such as fluoren-9-ylmethyl (Fm), fluoren-9-ylmethoxycarbonyl (Fmoc), and trifluoroacetyl (TFA) groups to protect side chains. Oligonucleotide is assembled after the peptide using standard benzoyl (Bzl) and isobutyryl (ibu) groups to protect the nucleobases. PEG-PS: polyethyleneglycol-polystyrene support.

Figure 8: Schematic representation of 8-aminopurine triads; a) 8-aminoadenine: T: T, c) 8-aminoguanine:C:C+ and c) 8-aminohypoxanthine:C:C+.

Figure 9: Schematic representation of oligonucleotide clamps designed to bind singlestranded polypyrimidine sequences (a-c) by triple helix formation. Bold dotted lines indicate Watson-Crick bonds. Thin dotted lines indicate Hoogsteen or reverse Hoogsteen bonds (TFO: triplex forming oligonucleotide sequence). 
Figure 10: a) Targeted oligonucleotide assemblies used as templates for gold nanostructures containing a biotin molecule-used to direct a streptavidine molecule to the middle of the structure; b) outline of the synthesis for two- and three-branched recognition elements. 
Figure 1

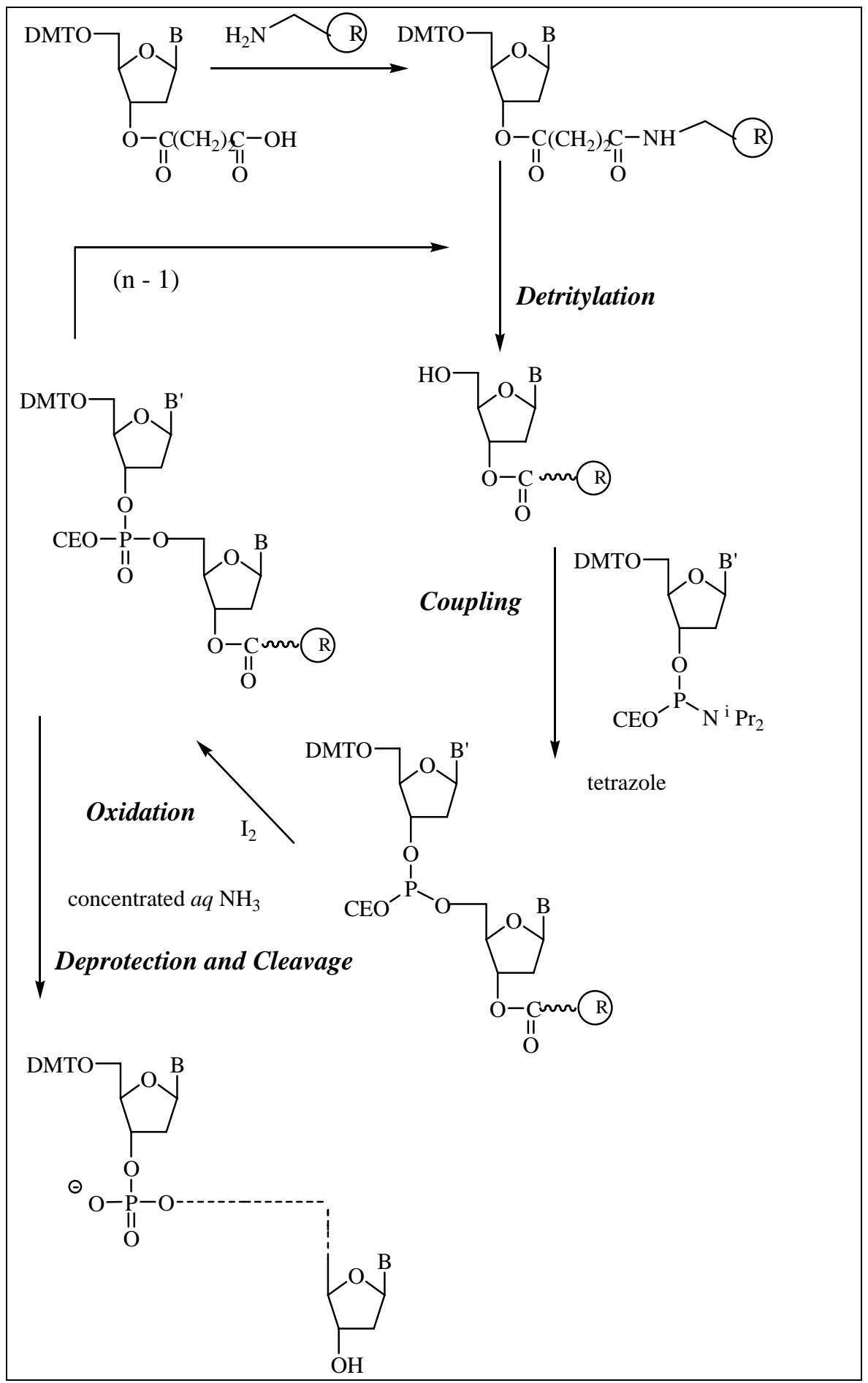


Figure 2

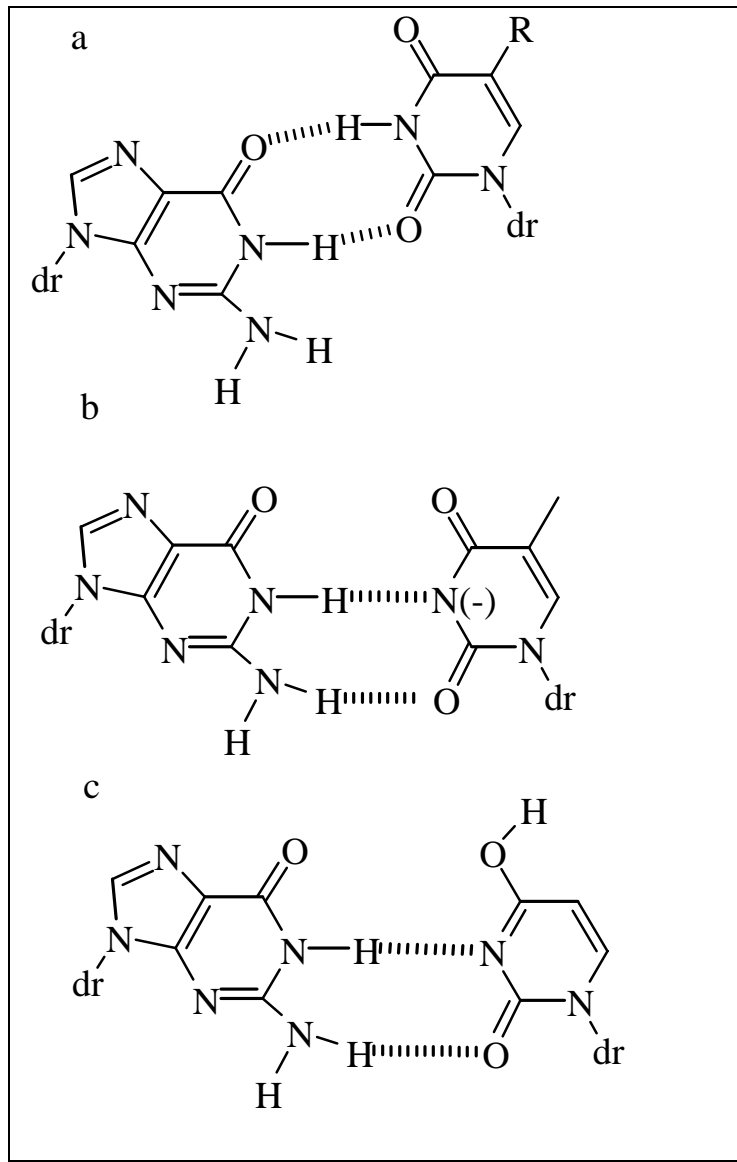


Figure 3

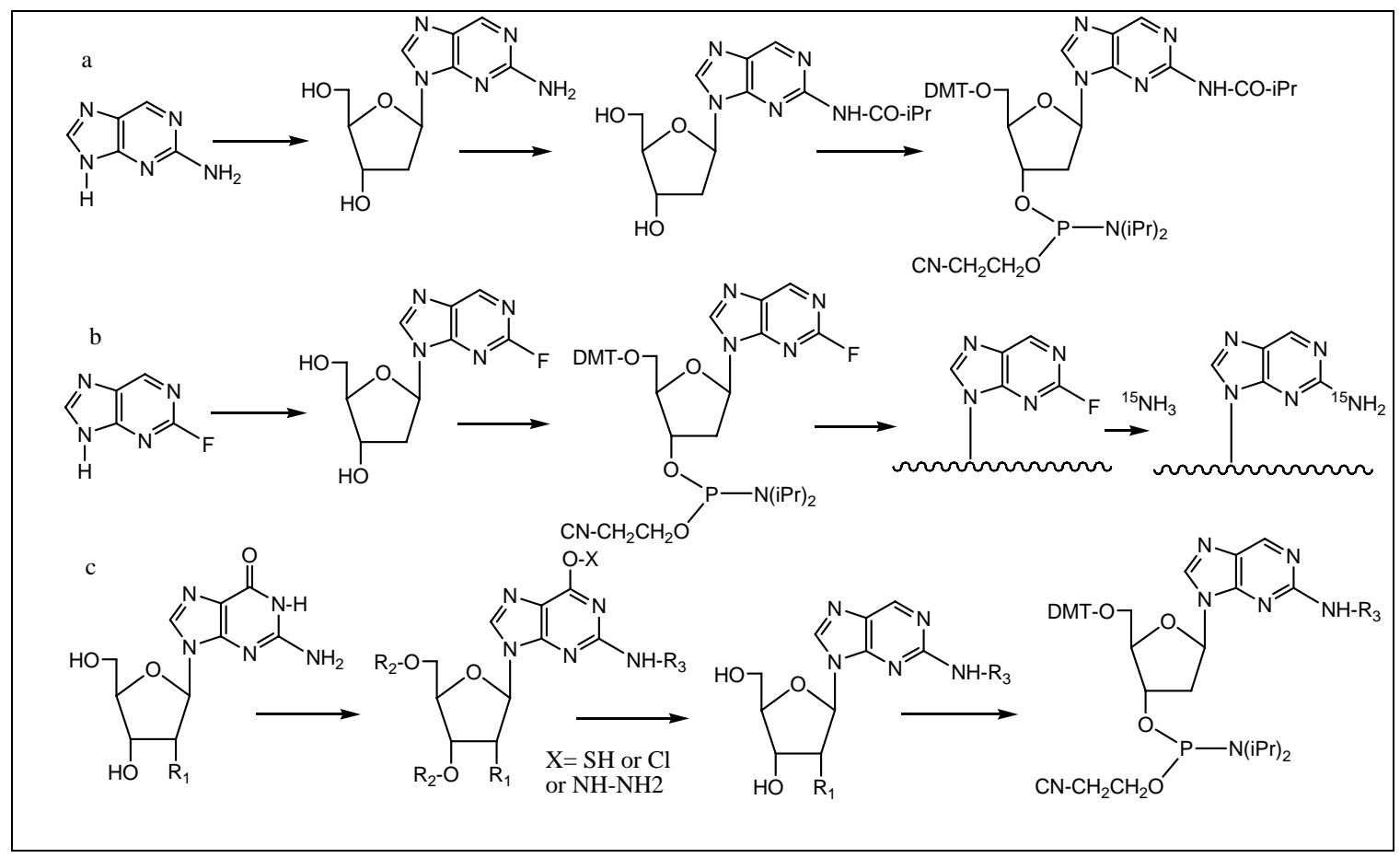


Figure 4

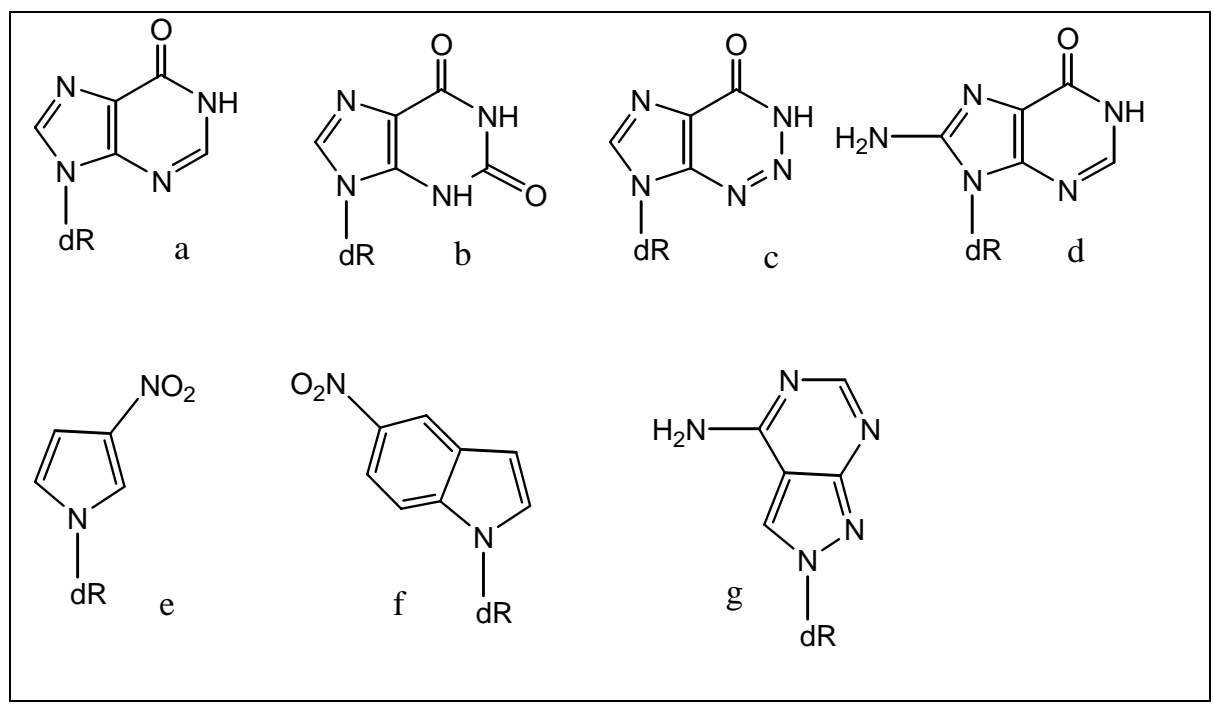


Figure 5
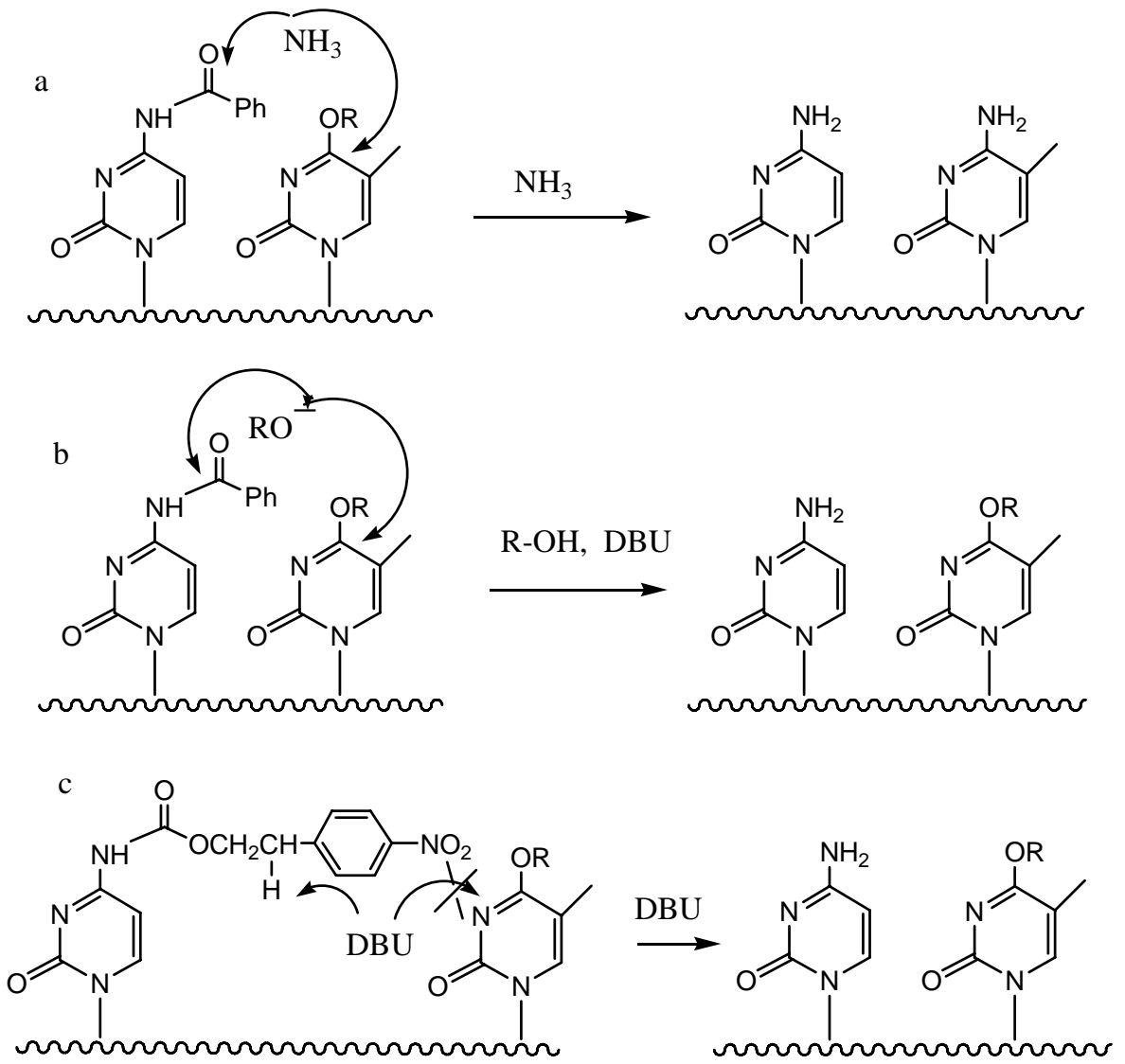
Figure 6

DMT-O- $\left(\mathrm{CH}_{2}\right)_{6}$-S-S- $\left(\mathrm{CH}_{2}\right)_{6}-\mathrm{OPO}_{2}-{ }^{{ }^{\prime}}{ }^{\prime} \mathrm{OLIGONUCLEOTIDE}{ }^{3}$-Succinyl-Support

aq. conc. $\mathrm{NH}_{3}$, dithiothreitol

HS- $\left(\mathrm{CH}_{2}\right)_{6}-\mathrm{OPO}_{2}-{ }^{-5}$ OLIGONUCLEOTIDE ${ }^{3}$

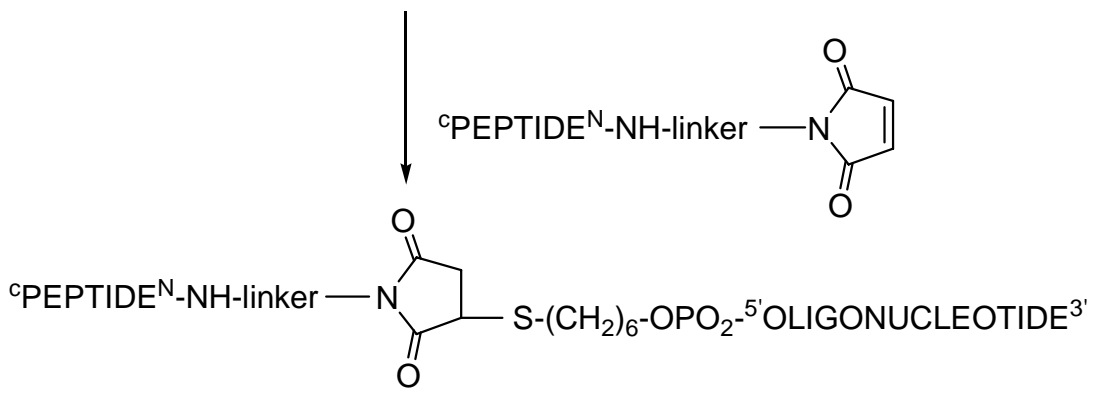


Figure 7

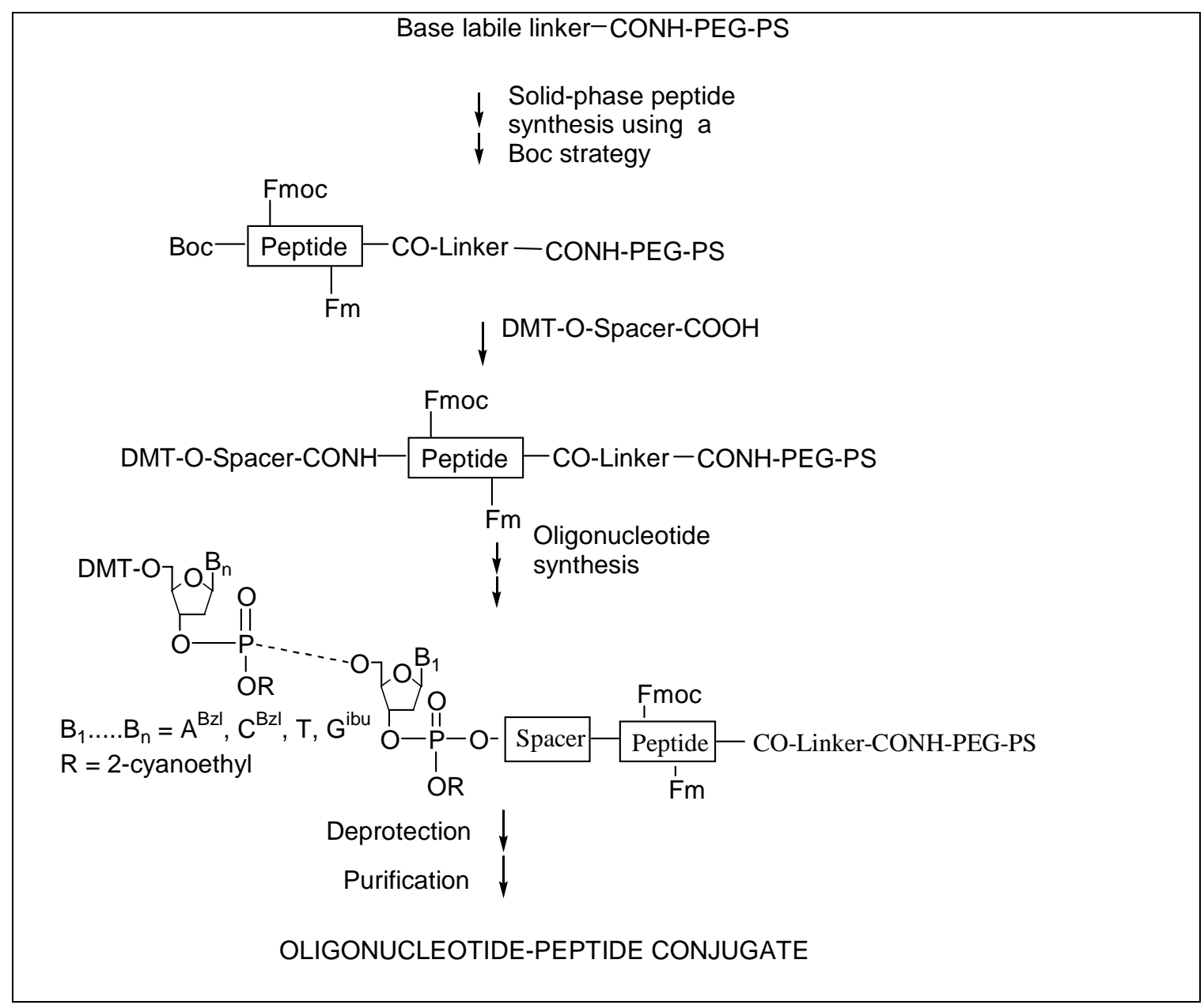


Figure 8

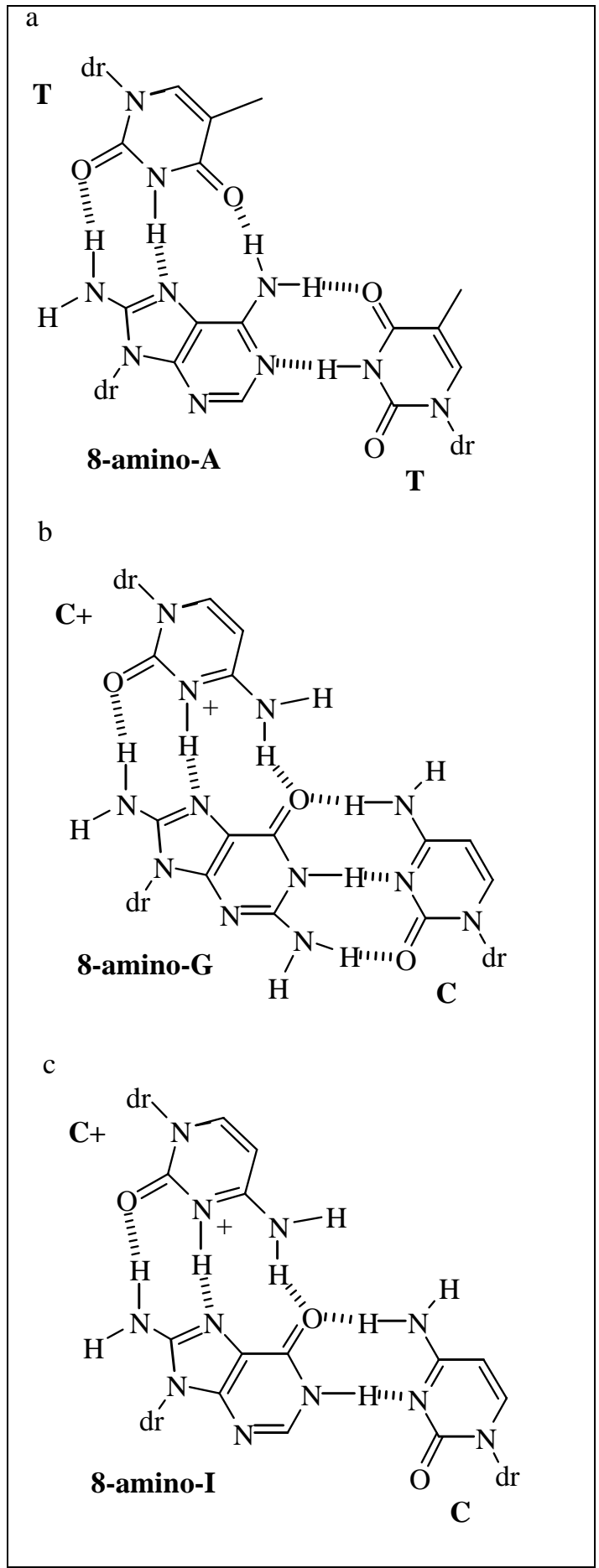


Figure 9

a

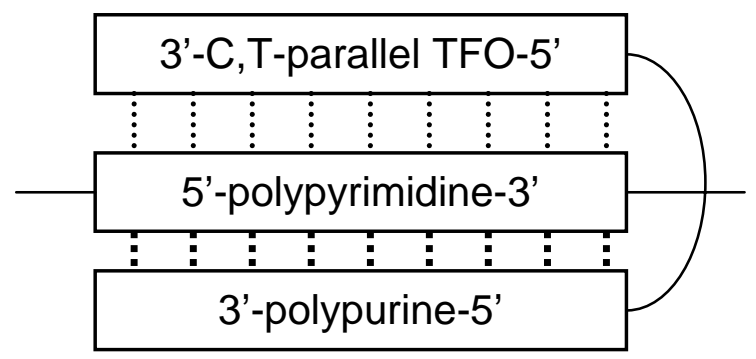

b

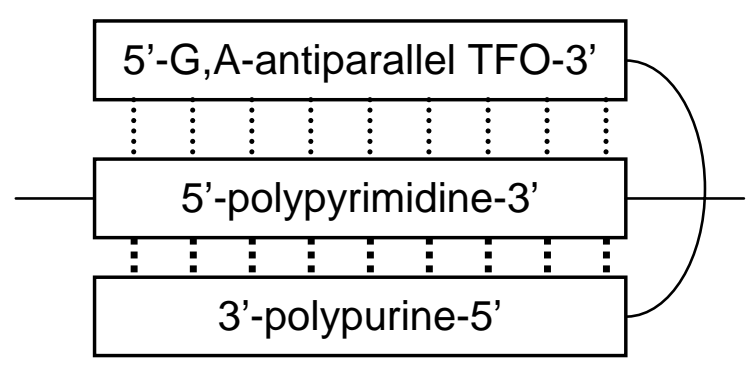

C

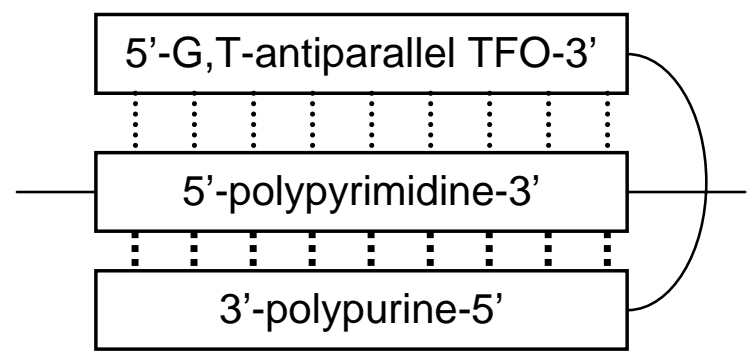


Figure 10

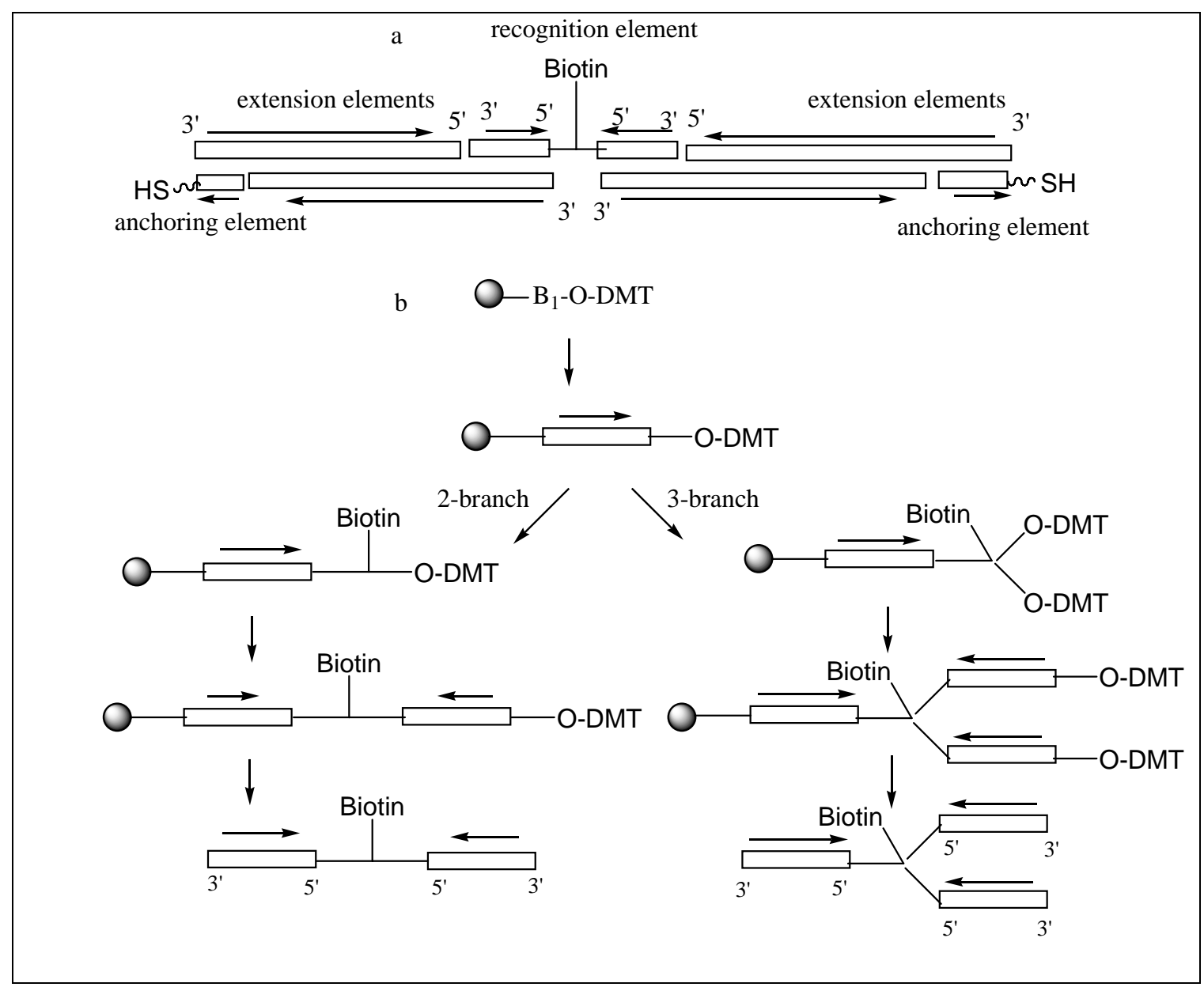

